do sino que la imagen misma es el cuerpo mutilado. La imagen de la violencia plasmada en un medio adquiere eficacia en el proceso del tránsito ritual. Ésta no resulta mera representación inmovilizada de un programa simbólico que requiere inmolar una víctima sacrificial: es su presencia manifiesta y de manera figurativa le confiere su energía; aquella tensión — fuerza atrapada — que permite que la imagen del hueso no sea una simulación sino él mismo.

Para finalizar, espero mostrar que el estudio de imágenes de violencia demanda un acercamiento o una participación interdisciplinaria. Los documentos y resultados que genere cada disciplina arrojarán acumulaciones específicas de información que, en conjunto, podrán demostrar su validez. Este acercamiento permitirá descifrar mejor las imágenes del sacrificio humano y del cuerpo desmembrado e indagar y postular las preguntas correctas. De este modo se entenderá de manera adecuada su función en el interior de una sociedad, en la que la violencia y su representación se insertan en un universo ideológico e iconológico. Dicha perspectiva requiere una postura comprehensiva, la cual admita, por más objetiva que se suponga, que su configuración arranca de posiciones ideológicamente formadas y antiguas preconcepciones. $^{*}$

\footnotetext{
* Agradezco los comentarios de los miembros del Seminario Arte y Sacrificio en el Mundo Indígena, del Posgrado en Historia del Arte de la Facultad de Filosofía y Letras de la Universidad Nacional Autónoma de México (semestre 20 I I-I).
}

\section{San Esteban Axapusco. Historia y arte Adriana Munguía Arenas}

México, Patronato Parroquial de San Esteban Proto Mártir/Tendiendo Puentes/Transformarte, 2010

por

ROGELIO RUIZ GOMAR

Un hecho cada vez más frecuente, sin perder por ello su carácter estimulante, es la aparición de libros que vienen a sumarse a los estudios de la llamada microhistoria, iniciados por Luis González. El que ahora nos ocupa es la primera aproximación a la historia de una modesta población del actual Estado de México, San Esteban Axapusco, a partir del monumento que al paso de los ańos se ha erigido como núcleo vital: su templo parroquial.

Por fin ha salido a la luz en forma de libro, aunque en edición casi privada y como homenaje póstumo, lo que en su origen fue el trabajo de tesis con que Adriana Munguía Arenas obtuvo en 2004 el grado de licenciada en Historia por la Facultad de Filosofía y Letras de la Universidad Nacional Autónoma de México, estudio que tuve el privilegio de dirigir, para el cual escogió como tema, precisamente, el devenir histórico de su pueblo, pero, mejor aún, el de la historia y el arte que contiene la iglesia dedicada al santo mártir patrono del mismo.

Consciente de que "parte importante del conocimiento de nuestro pasado" es el rescate de la historia de lugares y personas que nos rodean y de que, por lo mismo, un historiador no sólo debe ocuparse de los pueblos, 
personajes, sitios o eventos más importantes, sino también de las sociedades, los monumentos y los pequeños sucesos que se asentaron, se levantaron $u$ ocurrieron en sitios que no ocupan un lugar geográfico importante, pero que resultan significativos para esa comunidad, Adriana sostiene: "Éste es el caso [...] de San Esteban Axapusco, la iglesia de una comunidad un tanto perdida hacia el norte del Estado de México, pero que cuenta con un pasado digno de rescatarse, y sobre todo, con un acervo digno de conocerse".

Lo que la animó a ahondar en la historia de su pueblo fue el haber caído en la cuenta de la falta de estudios monográficos sobre la región y por supuesto de esta población en particular. En el mismo sentido, pero concretamente en lo referente al campo de la historia del arte, no pudo evitar constatar que en la historiografía habitual los estudiosos sólo se habían detenido a registrar la existencia del convento de Nuestra Seńora de la Concepción de Otumba, la vecina población y cabecera, y que aun en ese caso las menciones se restringían al estudio de la arquitectura y la escultura, dejando fuera el tema pictórico, no obstante que contaba con una colección más pequeña que la de Axapusco, en la que sin embargo existían obras de reconocidos maestros del periodo colonial, como José de Páez.

Para subsanar este pobre panorama, causado por la falta de interés de estudiosos, autoridades e instituciones, ella se abocó a estudiar la historia de su amado terruño. Tal es el origen del origen de este libro, al que con toda justeza intituló San Esteban Axapusco. Historia y arte, deseosa de contribuir a despertar en todos los miembros de la misma comunidad el orgullo de pertenecer a ella y de dar a conocer a propios y extrańos la singularidad de la rica colección de obras de arte que por diversas circunstancias se formó en su iglesia parroquial.

Para dotar de rigor a su estudio, la autora consultó varios archivos y echó mano de la bibliografía existente, extrayendo la información que consideraba importante rescatar; pero también se sirvió de esa metodología no siempre bien aprovechada que es la "historia oral”, con la cual consiguió recoger de diversos miembros de su entorno valiosas noticias transmitidas a lo largo del tiempo, corroborando así su conciencia de pertener a dicha comunidad.

Su estudio lo estructuró a partir de cuatro capítulos. En el primero ofrece una apretada revisión de la "situación geográfica" y los “antecedentes históricos” de la población. Como es fácil entender, organiza este capítulo en varios subtítulos para ir dando entrada a la "Época prehispánica", a la "Época colonial" (con la conquista, las encomiendas y el desarrollo de San Esteban en dicho periodo) y al siglo xix (en el que no puede menos que abordar el punto referente al "pulque y sus beneficios" y al advenimiento del ferrocarril), antes de concluir con una mención de los avatares de la zona durante la Revolución.

Dedica el segundo capítulo a la "Iglesia de San Esteban Axapusco". Brevemente nos recuerda el proceso evangelizador que se dio en toda esta zona, a cargo principalmente de la orden de San Francisco. Pero la aportación de la autora viene cuando informa de las distintas etapas constructivas y los artífices que intervinieron en algunas remodelaciones que fue experimentando el inmueble. De esta manera, aunque la escasez de noticias no le permite hacer un seguimiento puntual de todos los arreglos, recoge datos que adquieren importancia especialmente en el contexto 
local; así sucede cuando informa que a principios del siglo Xvin hubo necesidad de hacer algunas reparaciones al templo, pero como la situación no mejoraba, se decidió construir uno nuevo, cuyas obras comenzaron en I743, a cargo del maestro mayor Juan de Alva (de quien se dice tenía 62 años de edad, era vecino del pueblo de San Juan Teotihuacan y se le pagaban cuatro pesos y cinco reales en cada visita) y de otros operarios como Salvador Antonio, acaso el sobrestante (que ganaba seis reales diarios), Manuel Esteban, Pedro García, el maestro albañil Pedro Antonio y los canteros Marcos Antonio, Bernabé Carlos y José de la Trinidad (a quienes se pagaba dos reales y medio por tarea). Como bien infiere la autora, es probable que todos ellos también fuesen vecinos de la región, pues en los documentos mencionados se especifica que los gastos de mantenimiento de sus herramientas, así como la comida diaria, corrían a cargo de la comunidad. Y aunque al parecer las obras avanzaron con rapidez, pues para abril de 1745 se había construido una bóveda y uno de los arcos de la iglesia, no sabemos cuándo se concluyó; acaso ello ocurrió antes de 1767 , año en que fue elevada a la categoría de parroquia. Perteneció a la arquidiócesis de México hasta 1960, cuando se integró a la diócesis de Texcoco.

Los capítulos tercero y cuarto se consagran a la presentación del muy útil catálogo de obras de arte elaborado por la autora. En el entendido de que la iglesia misma es una obra en sí, inicia este apartado con la descripción del inmueble, tanto de su exterior como de su interior, considerando todas sus partes (atrio, capillas posas, portal; fachada, torre; nave, cúpula, retablos, imágenes, etc.). Con buen juicio consigna también las obras que ya desaparecieron, pero de las cuales hay tes- timonio de su existencia, como el ciprés en el presbiterio y los altares neoclásicos que por un tiempo lucieron en la nave, los cuales, a su vez, seguramente habían sustituido unos anteriores de gusto barroco. De otros cambios que la iglesia experimentó, bien hace la autora en registrar que la herrería de la barda del atrio se adaptó a principios del siglo $\mathrm{xx}$, la cual, al igual que los retablos colaterales colocados en el presbiterio, se trajeron a este lugar de la Colegiata de Nuestra Señora de Guadalupe por quien era a la sazón abad de la misma, monseñor Gregorio Aguilar, originario precisamente de San Esteban Axapusco.

Dedica un breve espacio a hablar de las esculturas conservadas en la iglesia, tanto las que ocupan su lugar en el retablo mayor como las que quedan aisladas — entre las cuales sobresale una de san Francisco de Asís-, y por supuesto consagra otro apartado para estudiar el retablo en sí, del que subraya es "el único que subsiste en la zona de semejantes dimensiones, de madera tallada y dorada, al estilo barroco".

Dado el interés por destacar el inusitado y rico acervo de pinturas que conserva la iglesia de San Esteban Axapusco, la autora dedicó el cuarto y último capítulo al análisis y catalogación del mismo, el cual, sin contar las de la cúpula (ejecutadas en 1926 por José Ramírez), está conformado por 5 I obras de calidad poco homogénea y variada cronología, a las que por cuestiones meramente metodológicas organizó en núcleos temáticos. En el primer apartado se encuentran ocho cuadros con representaciones de la Virgen María. Aquí destacan los relacionados con "Arellano" (uno firmado y dos atribuidos) y corresponden en realidad a una familia de al menos dos pero acaso tres o cuatro pintores que en el paso del siglo XVII al XVIII llevaron ese apellido, sin que por ahora 


\section{8}

LI B RO S podamos acercar estas obras a alguno de ellos. Viene luego un par de lienzos con arcángeles, acaso restos de una serie mayor.

Como era lógico esperar, también se conservan varios cuadros con la representación de distintos pasajes de la vida de Cristo. Sobresalen los dos de formato apaisado ejecutados por Juan Carlos de Medina - atractivo pintor, aunque prácticamente desconocido, activo en la primera mitad del siglo XviII- así como también seis lienzos ovales que ilustran distintos momentos de la Pasión. Mención especial merece un cuadro de autor anónimo que retrata a Jesús cuando expulsó a los mercaderes del templo, tanto por tratarse de un tema muy poco representado por los artistas del México virreinal como por el dinamismo de su composición, al parecer extraída de Rubens, y la buena calidad de su factura.

El núcleo más variado de pinturas es el dedicado a la representación de santos. De san Esteban, el santo titular, hay tres obras, si bien ninguna es de elevada calidad. Sobresale un Apostolado de autor anónimo, al parecer completo, compuesto por I 4 lienzos en los que las figuras quedan de medio cuerpo sobre fondos oscuros; para su cabal identificación, cada uno lleva inscrito su nombre y porta el instrumento de su martirio. Estas obras, además, lucen gallardos marcos con copetes calados de estirpe rococó. Firmado por Francisco Cervantes, artífice hasta ahora desconocido, se guarda un Martirio de san Lorenzo. Pero sin duda el lienzo de mayor calidad de todo el acervo es el que representa a un santo obispo — desafortunadamente no identificado- sentado ante su mesa de trabajo con una pluma en la mano y dirigiendo la cabeza hacia lo alto. Se trata de una pintura de altos vuelos de autor igualmente sin identificar aún, pero cuyo lenguaje plástico está claramente asociado al de Cristóbal de Villalpando. Finalmente se conserva, aunque seccionado en seis partes, un "retablo fingido" dedicado a san Antonio de Padua, pues entre los trazos de pilastras estípites, cornisas y molduras simuladas subsisten seis escenas de la vida de dicho santo. Este conjunto interesa de manera creciente por el escaso número de obras de ese tipo que han subsistido hasta nuestros días.

Como bien advierte la autora en las conclusiones, su estudio no pretende ser exhaustivo ni fue concebido de manera cerrada. Lo entendió, más bien, como el primer acercamiento al tema y una invitación para que, a la vista de éste, vengan nuevos y más ambiciosos estudios. Sea como fuere, es indudable que el libro que nos ocupa viene a contribuir de manera significativa al conocimiento de la "historia" y el "arte" del pueblo de San Esteban Axapusco, mismo que así logra adelantarse a otras poblaciones más grandes y de mayor peso, a lo largo y ancho de nuestro país, que no cuentan aún con un estudio propio. A través de sus páginas, aunque pensadas y dirigidas principalmente a ella misma y a sus coterráneos, todos habremos de aprender a encontrar razones para valorar nuestras raíces y así estar mejor equipados para velar por la salvaguarda de las obras de arte que han llegado hasta hoy día, no sólo de San Esteban Axapusco, sino de todo el país. 